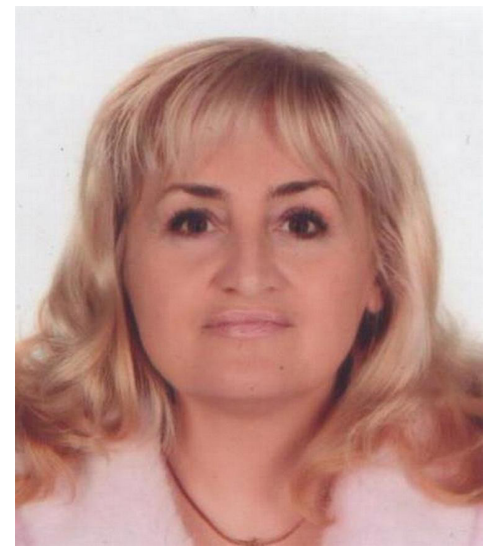

\author{
Наталія Салига, \\ кандидат педагогічних наук, доцент кафедри \\ педагогіки імені Богдана Ступарика, \\ ДВНЗ «Прикарпатський національний університет \\ імені Василя Стефаника» \\ (м. Івано-Франківськ, Україна)
}

\author{
Nataliya Salyha, \\ $\mathrm{PhD}$ in Education, Associate Professor, \\ Department of Pedagogy, \\ Vasyl Stefanyk Prekarpation National University \\ (Ivano-Frankivsk, Ukraine) \\ natalii58@ukr.net
}

УДК 37.015.31:172.15

\title{
НАЦІОНАЛЬНО-ПАТРІОТИЧНІ МОТИВИ У ДІЯЛЬНОСТІ МИХАЙЛА БАЗНИКА
}

Анотація. У статті висвітлено прогресивні ідеї національно-патріотичного виховання дітей і молоді в діяльності та творчій спадщині Михайла Базника. На основі аналізу педагогічної діяльності та творчої спадщини галицького педагога автор робить акцент на таких завданнях виховання сучасного молодого покоління, як: любов та повага до рідної мови, знання історії свого народу, його звичаїв і традицій тощо. Обґрунтовано важливість творчого доробку Михайла Базника, використання якого сприяє вдосконаленню педагогічного процесу, відповідає вимогам сьогодення. Сучасні дослідники усе частіше звертаються до надбань педагогічної думки 20-30-х років минулого століття. У цей період на перше місце виходять питання школи та освіти, розробляються теоретичні основи національної школи. І заслуга в цьому, в першу чергу, самовідданих трудівників на ниві освіти, які своєю працею сприяли національному поступові. Серед них - галицький педагог Михайло Базник, якому довелося пережити складні життєві обставини на чужині, важкі воєнні і повоєнні роки, примножувати багатовікову спадщину в царині національного виховання дітей та молоді. Відсутність дослідження із зазначеної теми в українській історико-педагогічній науці дало поштовх до поглибленого аналізу його педагогічної спадщини. Наукові погляди Михайла Базника в галузі педагогіки та психології, його плідна і невтомна праця і донині не поціновані належним чином. Михайло Базник відноситься до тих культурно-освітніх діячів Галичини, які сприяли культурному та освітньому розвитку народу.

Ключові слова: творча спадщина Михайла Базника, національно-патріотичне виховання, патріотичні почуття, національна школа, освіта, вчитель.

\section{NATIONAL-PATRIOTIC IDEAS OF MYKHAILO BAZNYK}

Abstract. The article highlights progressive ideas of the national-patriotic education of children and youth in activity and creative heritage of Mykhailo Baznyk. The analysis which is based on pedagogical activity and creative heritage of the Galician pedagogue let the author emphasize such tasks of educating modern young generation as: love and respect for the native language, knowledge of the history, customs and traditions of own people. There have also been proved the importance of M. Baznyk's creative work which contributes to the development of the pedagogical process and meets the present time demands. Modern scholars are increasingly turning to the achievements of pedagogical thought of 1920's and 1930's. During this period, the issues of school and education take the first place, and the theoretical foundations of the national school are being developed. The credit for this goes, first of all, to selfless laborers in the field of education whose work contributed to the national progress. These include the Galician pedagogue Mykhailo Baznyk who managed to survive the difficult living conditions in a foreign country, hard war and postwar years and to multiply the centuries-old legacy in the field of national education of children and youth. The lack of research on this topic in the Ukrainian historical and pedagogical science gave impetus to an in-depth analysis of his pedagogical heritage. The scientific views of Mykhailo Baznyk in the field of pedagogy and psychology, his fruitful and tireless work aren't duly recognized. Mykhailo Baznyk belongs to those cultural and educational figures of Galicia who contributed to the cultural and educational development of the people.

Keywords: creative heritage of Mykhailo Baznyk, national-patriotic education, patriotic feelings, national school, education, teacher.

\section{ВСТУП}

Постановка проблеми. Сучасні дослідники усе частіше звертаються до надбань педагогічної думки 2030-х років минулого століття. У цей період на перше місце виходять питання школи та освіти, розробляються теоретичні основи національної школи. І заслуга в цьому, в першу чергу, самовідданих трудівників на ниві освіти, які своєю працею сприяли національному поступові. Серед них - галицький педагог Михайло Базник, якому довелося пережити складні життєві обставини на чужині, важкі воєнні і повоєнні роки, примножувати багатовікову 
спадщину в царині національного виховання дітей та молоді. Відсутність дослідження із зазначеної теми в українській історико-педагогічній науці дало поштовх до поглибленого аналізу його педагогічної спадщини.

Аналіз останніх досліджень і публікацій. Просвітницька діяльність і педагогічні погляди Михайла Базника недостатньо досліджені. Життєвий шлях та творчий доробок галицького просвітянина вперше подається у дослідженнях В. Вериги, В. Олійника, І. Пелипейка, Ф.Погребенника та Я. Погребенник. Їхні напрацювання містять чимало цінної інформації із зазначеної проблеми.

МЕТА І ЗАВДАННЯ ДОсЛІДЖЕНнЯ. Мета статті - розкрити творчу спадщину Михайла Базника в контексті сучасних педагогічних ідей, охарактеризувати його як педагога, активного громадського діяча, проаналізувати його педагогічні погляди та просвітницьку діяльність.

МЕТОДИ ДОсЛІДЖЕНнЯ: теоретико-методологічний та ретроспективний аналіз наукових джерел і теоретичних положень означеної проблеми.

\section{РЕЗУЛЬТАТИ ДОСЛІДЖЕННЯ}

Влітку 2019 року виповниться 130 років з дня народження Михайла Базника (1889-1976) учителя галицької школи, члена Українського педагогічного товариства у Львові, учасника визвольних змагань, автора багатьох праць з проблем виховання і навчання, методиста, директор чотирикласної народної школи.

Михайло Базник народився 3 червня 1889 р. в с. Целіїв Гусятинського району Тернопільської області у селянській родині. Навчався в Тернопільській гімназії, а упродовж 1908-1912 рр. - в українській учительській гімназії в м. Заліщики. Вчительську діяльність розпочав у с. Верволинцях, а згодом - і в Лисівцях Заліщицького повіту (1913-1914рр.). Все життя присвятив Михайло Базник учительській та громадській діяльності.

Михайло Базник був засновником і директором української чотирикласної народної школи у Копичинцях. Вчив і виховував дітей в дусі любові до свого народу, його національних звичаїв і традицій. Виступаючи у 1923 р. з нагоди завершення навчального року, він говорив: «Лише українська школа, українське вчительство виховує українських дітей на справжніх і свідомих громадян українського народу» (Архів музею освіти Прикарпаття, с. 25). У цей період він друкує статті у педагогічних часописах («Учительське слово», «Життя і знання», «Шлях навчання і виховання», «Добробут»), де відстоює право українців на рідну мову та національну школу.

Через виразну проукраїнську позицію Михайлові Базнику заборонили працювати в школах Галичини. Сім'я змушена була виїхати в с. Вронів на Познаньщину (1925-1930), де Михайло Якович працював директором початкової школи, а дружина - вчителькою. Як згадує їх донька, Ярослава, «скривджені польсько-шляхетською владою, відірвані від України, батько і мати любили своїх учнів, у приязні жили з їх батьками-селянами - вони були не винні у тому, українці в польській державі, на своїй споконвічній землі зазнавали утисків і приниження. Так мої батьки ділили своє серце між українськими і польськими дітьми. Вони були гуманістами, вихованими на високих патріотичних ідеалах свого народу, за волю якого мій батько воював у лавах Української Галицької Армії» («Український альманах. Об’єднання українців у Польщі», 1997, с. 394).

у 20-30-х роках минулого століття Михайло Базник уже засобом друкованого слова боровся за українську національну школу. На сторінках львівської преси були опубліковані такі його праці, як: «Кіно на услугах шкільного навчання» (1927), «Нові (модерні) шляхи сучасного виховання і навчання» (1927), «Самодіагноз вчителя», «Педологія основа виховання і навчання» (1928), «Кершенштейнерівське розуміння творчої школи» (1928), «Народна школа і вибір звання» (1930). Підготував до друку статтю «Методи педагогічних досліджень» та підручник «Вибір звання. Практичний підручник для школи і дому». На жаль, в силу не залежних від автора причин він не був надрукований.

Польським властям не подобалась активна громадська діяльність вчителя-українця, і Михайло Базник переселився на Гуцульщину. Будучи завідувачем райпедкабінету м. Косова, часто виступав з доповідями на нарадах учителів. Ось як згадує свого колегу методист Косівського райвно Ігор Пелипейко: «Михайло Базник був взірцем учителя дорадянської школи: бездоганно ввічливий, акуратний, витриманий, точний до педантичності. Не пам'ятаю випадку, коли б він підвищив голос, дозволив собі піддатися емоціям. Це була людина високої культури» (Пелипейко І., 2001, с. 2).

Все свідоме життя в серці М. Базник цікавився творчістю Лесі Українки, якій присвітив свої статті та доповіді («Свято Лесі Українки» (1938), «Леся Українка - національний співець» (1943)). Особливо глибоко він відчував національну ідею творчості поетеси. «Національна ідеологія Лесі Українки» - це у нас зовсім щось нове, - писав Михайло Базник. На місце пацифізму поставила вона ідею войовничого націоналізму. Цей націоналізм був для неї самоціллю, він не шукав жодного виправдання» (Із статті «Свято Лесі Українки». Автограф, Косів, кінець березня 1938 р.) (Архів музею освіти Прикарпаття, с. 38).

Працюючи вчителем української мови та літератури, Михайло Базник прагнув привити своїм вихованцям любов до рідної літератури, сформувати почуття національної гордості. Він часто розповідав учням про творчість Лесі Українки, Т. Шевченка, І. Франка, цитував напам'ять їхні твори. У промові на Шевченківському святі 1922/1923 навчального року в Копичинцях Михайло Базник закликав молодь: «Шевченко домагається від нас праці над власною освітою і освітою всього народу, бо тільки освічений народ може постояти за своє право на життя. Українські діти і українська молодь мусять слухати цього голосу і здобувати знання, щоб знанням послужити народові у слушний час. Через освіту український народ поставить себе у ряди інших культурних 
народів і прискорить хвилину, щоб виконати останню частину Заповіту - у великій, вольній, новій сім'ї пом'янути Тараса добрим і грімким на весь світ словом» (Архів музею освіти Прикарпаття, с.15).

Галицький просвітянин закликав молодь бути голосом дзвона, що будить усіх зі сну. Він і сам був справжнім дзвонарем, бо закликав любити свій народ, дбати про нього.

Високо цінив Михайло Базник національного генія І. Франка: «Франко не був офіційним учителемвихователем, а проте про ніякого з наших національних велетнів не зможемо з таким правом сказати, як про нього: «Великий учитель» (Архів музею освіти Прикарпаття, с. 36).

Домінуючою ідеєю педагогічної системи Михайла Базника була народність. Як прихильник національної системи освіти він прагнув відповісти на питання: якою має бути українська школа, якими засобами і шляхами її будувати. Він довів, що в процесі навчання і виховання в національній школі повинна формуватись національна свідомість, без якої неможливий повноцінний внутрішній світ людини-громадянина. «Теперішня школа, - писав М. Базник, - повинна в руках українського учительства перемінитися з навчаючої інституції в школу виховання характеру й національної свідомості» (Базник М., 1922, с. 2).

Аналізуючи зарубіжні педагогічні системи, Михайло Базник розглядав українську педагогіку як невід'ємну складову європейської педагогічної думки, бачив їх нерозривний взаємозв'язок, висловлював думки щодо організації народного виховання в Україні, прагнув адаптувати їх до українських реалій. Учений був переконаний, що єдиний шлях до національного добробуту і культури веде через свою рідну школу. «Необхідно поставити школу практично так, - писав він, - щоб вона з крови й кости була нашою рідною, не відбігала далеко від нашої національної традиції, а при цьому стояла на відповідному високому рівні новітньої школи сучасних культурних народів, щоб наша педагогіка, не нехтуючи скарбами національної душі і культури, могла вільно і з користю асимілювати великі здобутки модерної наукової педагогіки освіченого людства» (Базник М., 1922, с. 2).

На основі аналізу виховної практики досліджень українських і зарубіжних вчених Михайло Базник утверджується в думці, що національні цінності формуються в процесі розвитку особистості, набуття нею соціального досвіду, а успіхи школи у вихованні забезпечуються єдністю народної і наукової педагогіки, вітчизняної та світової. Національне виховання педагог розглядав як природну потребу нації, а мету і завдання бачив у «витворенні найзагальніших виховних ідеалів» («Тестові проби в школі». Рукопис ) (Архів музею освіти Прикарпаття, с.12).

Як просвітитель вірив М. Базник у всемогутність людського розуму, вважав, що саме від освіти залежить і економічний, культурний розвиток народу, його матеріальний добробут: «Народ, який має багато освічених одиниць, буде освіченим, або інакше кажучи, культурним народом» (Архів музею освіти Прикарпаття, с. 13).

Чільне місце в творчому доробку педагога займає образ народного вчителя, який повинен любити дітей і свою професію, бути хорошим фахівцем, любити рідну мову, історію, добре знати народні звичаї і традицій, впливати на формування національної свідомості українців.. М. Базник писав, що праця народного вчителя вкрай важка і багатогранна, бо «поза школою на нього чекає багато праці: читальня «Просвіти», фінансова інституція, кооперативна спілка, кадри неграмотних, «Січі» й «Соколи», читальні й церковні хори і т.д. виглядають допомоги свого вчителя, щоб рятуватися від смерті» (Базник М., 1922).

Турбуючись про відсутність літератури з психології, М. Базник у «Передньому слові до праці «Педологічні досліди в школі» на поч. 20-х років минулого століття писав: «Маючи на увазі багату педагогічну літературу в галузі експериментальної психології на Заході і ті проблеми виховання, що їх там уже вирішила шкільна практика з одного боку і вбогість української педагогічної літератури з другого та обстаючи точку зору, що кожна навіть найдрібніша праця українською мовою в галузі експериментальної психології є певним надбанням для української педагогічної літератури і рідного шкільництва - я не завагався видати цю працю друком» (Архів музею освіти Прикарпаття, с. 13). На жаль, ця праця так і не була надрукована.

Михайло Базник був глибоким знавцем людей, що дало йому можливість сказати нове слово в галузі цілого ряду психологічних знань, наблизити своє педагогічне вчення до педагогічної практики. Вчений писав про необхідність звернути свої погляди до вивчення психології дитини. «На наших очах твориться нова наука про дитину, педологія, що ставить собі за мету обстежити дитину у їі фізичних, розумових і моральних виявах. Вона, ця наука разом з тим стверджує, що лише точне вивчення вихованця може дати в результаті раціональне виховання і навчання», - писав М. Базник у статті «Тестові проби в школі» (Рукопис. Целіїв, 1921, червень-липень) (Архів музею освіти Прикарпаття, с.12). Про колосальну роботу над цією працею свідчать експериментальна таблиця тестів та список використаної літератури з тринадцяти прізвищ польських авторів 20-х років 3 питань педології, експериментальної психології, педагогіки, психологічної педагогіки, шкільництва (Архів музею освіти Прикарпаття, с. 12). На думку Михайла Базника, вчитель, який втрачає психологічний контакт з дітьми, не має морального права працювати з ними.

Як і інші українські просвітителі, галицький просвітянин писав про необхідність психологічної підготовки дітей до праці. За його переконанням, саме в праці людина має найбільше можливостей реалізувати себе, тим самим принести користь народові. Працю, інтереси і задатки до неї педагог ставить у пряму залежність, маючи на увазі працю за покликанням. Винятково важливим є положення вченого про те, що праця є джерелом морального становлення дитини, а вчитель повинен так організувати роботу, щоб «особистою працею дитини виховувати і розвивати в ній самостійність, силу волі енергію, фізичні і моральні сили» (Базник М., 
1927 , с.14). Коли на початку 60-х років XX ст.. в педагогіці жваво обговорювались питання вибору професії, профорієнтаційної роботи, то галицький сільський вчитель ще в 1930 р. надрукував цю статтю.

Останні роки свого життя Михайло Базник жив у Києві, постійно цікавився педагогічними проблемами, редагував раніше написані статті, готував нові розробки в галузі педагогіки та методики навчання, прагнув деякі з них опублікувати. Педагогічні погляди Михайла Базника значно випереджали свій час. А хто випереджає час і робить усе не так, як було до цього, того карають. Так траплялося з багатьма особистостями. Так сталося і 3 Михайлом Базником. Жодної із своїх праць у післявоєнний період Михайло Базник не зміг опублікувати, не зміг оприлюднити власного бачення шляхів розвитку школи.

Як згадує його дочка Ярослава, Михайло Базник часто перечитував книжки із своєї бібліотеки, «не раз линув думкою у рідний край на Поділля, де жила його родина, яка постраждала в часи сталінського терору, розповідав про події Першої світової війни, визвольні змагання в лавах УГА. Перед очима проходили роки вимушеного перебування на чужині, вчителювання на Гуцульщині, якій віддав стільки років самовідданої праці і щирої любові. 3 кожним роком і днем усвідомлював, що вічний спочинок знайде на берегах Дніпра біля могили своєї дружини» («Український альманах. Об’єднання українців у Польщі», 1997, с. 395).

Помер Михайло Базник 6 жовтня 1976 року в Києві. Похований на Байковому кладовищі.

\section{ВИСНОВКИ ТА ПЕРСПЕКТИВИ ПОДАЛЬШИХ ДОСЛІДЖЕНЬ}

Наукові погляди Михайла Базника в галузі педагогіки та психології, його плідна і невтомна праця і донині не поціновані належним чином. Михайло Базник відноситься до тих освітніх діячів, які сприяли культурному та освітньому розвитку народу. Ті погляди, які він висловлював ще на початку XX ст. щодо реалізації питань національної школи, перекликаються із запитами сучасних педагогів. А тому необхідно повернути національній педагогіці ім'я і славу невтомного сподвижника народної освіти.

\section{СПИСОК ВИКОРИСТАНИХ ДЖЕРЕЛ}

Архів музею освіти Прикарпаття. Інв. № 2195.

Базник, М. (1927). Нові модерні шляхи сучасного виховання і навчання. Шлях навчання і виховання. Львів, 11, 11-15.

Базник, М. (1922). Під новий рік. Учительське слово. 11, Листопад-грудень.

Верига, В. (1993). Там, де Дністер круто в єеться: історичний нарис виховно-освітньої політики в Галичині на прикладі учительської семінарії та гімназії в Заліщиках, 1899-1939. 2-е вид., випр. Львів : Каменяр.

Пелипейко, І. (2001). Косів: Люди і долі. Краєзнавчий довідник. Косів: Писаний камінь, 91-92.

Український альманах. Об’єднання українців у Польщі. (1997). Варшава. 392-395.

\section{REFERENCES}

Arkhiv muzeju osvity Prykarpattja. Inv. № 2195.

Baznyk, M. (1927). Novi moderni shljakhy suchasnogho vykhovannja i navchannja. Shljakh navchannja i vykhovannja. Ljviv, 11, 11-15.

Baznyk, M. (1922). Pid novyj rik. Uchyteljsjke slovo. 11, lystopad-ghrudenj.

Verygha, V. (1993). Tam, de Dnister kruto v`jetjsja: istorychnyj narys vykhovno-osvitnjoji polityky v Ghalychyni na prykladi uchyteljsjkoji seminariji ta ghimnaziji v Zalishhykakh, 1899-1939. 2-e vyd., vypr. Ljviv : Kamenjar.

Pelypejko, I. (2001). Kosiv: Ljudy i doli. Krajeznavchyj dovidnyk. Kosiv: Pysanyj kaminj, 91-92.

Ukrajinsjkyj aljmanakh. Ob'jednannja ukrajinciv u Poljshhi (1997). Varshava. 392-395. 